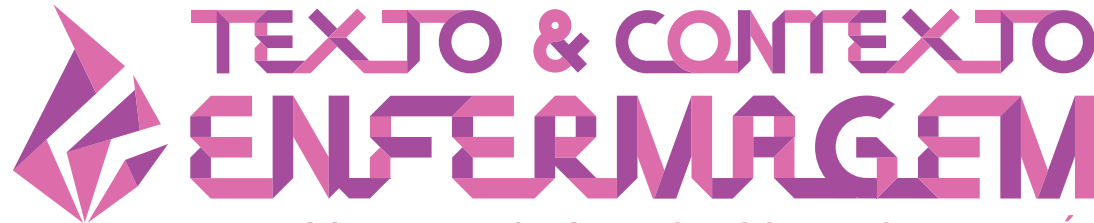

TEXT \& CONTEXT NURSING TEXTO \& CONTEXTO ENFERMERÍA

\section{PRESENCE OF THE FAMILY DURING EMERGENCY CARE: PATIENT AND FAMILY LIVING}

\section{Mayckel da Silva Barreto ${ }^{1}$ Cristina Garcia-Vivar ${ }^{2}$ Laura Misue Matsuda ${ }^{3}$ (c) Margareth Angelo ${ }^{4}$ Magda Lúcia Felix de Oliveira ${ }^{3}$ Sonia Silva Marcon ${ }^{3}$ []}

${ }^{1}$ Faculdade de Filosofia, Ciências e Letras de Mandaguari. Departamento de Enfermagem, Mandaguari, Paraná, Brasil. ${ }^{2}$ Universidad de Navarra, Departamiento de Enfermeria. Pamplona, Navarra, Espanha. 3Universidade Estadual de Maringá, Programa de Pós-graduação em Enfermagem. Maringá, Paraná, Brasil. ${ }^{4}$ Universidade de São Paulo. Departamento de Enfermagem, São Paulo, São Paulo, Brasil.

\begin{abstract}
Objective: to understand how family members and adult patients perceive the family's presence in emergency care.

Method: qualitative study that used Symbolic Interactionism as a theoretical reference and the Data Grounded Theory as a methodological reference. Data collection took place in two emergency rooms, located in southern Brazil, between October 2016 and February 2017, through open interviews with four patients and eight relatives. Results: the relative presence in the emergency care was signified/perceived as positive, due to the benefits identified for patients, family members and health professionals. However, the experience was also marked by mishaps for the family-patient relationship, such as fear, doubts, anguish about the forced separation of family members and the experience of feelings of regret.

Conclusion: due to the fact that the presence of the family in the emergency room is perceived as positive and beneficial, it is suggested that the health services, to the extent of their possibilities, implement this practice. However, such units need to be better prepared to mitigate the pitfalls faced by patients and their families.
\end{abstract}

DESCRIPTORS: Family. Patients. Emergency medical services. Emergencies. Perception. 


\section{PRESENÇA DA FAMÍLIA DURANTE O ATENDIMENTO EMERGENCIAL: VIVÊNCIA DE PACIENTES E FAMILIARES}

\section{RESUMO}

Objetivo: compreender como familiares e pacientes adultos percebem a presença da família no atendimento emergencial.

Método: estudo qualitativo que utilizou o Interacionismo Simbólico como referencial teórico e a Teoria Fundamentada nos Dados, como referencial metodológico. A coleta de dados ocorreu em duas salas de emergência, localizadas no sul do Brasil, entre outubro de 2016 e fevereiro de 2017, por meio de entrevistas abertas com quatro pacientes e oito familiares.

Resultados: a presença familiar no atendimento emergencial foi significada/percebida como positiva, em decorrência dos benefícios identificados para pacientes, familiares e profissionais de saúde. Entretanto, a experiência também foi marcada por percalços para o binômio familiar-paciente como, por exemplo, medo, dúvidas, angústia pela separação forçada dos membros da família e a vivência de sentimentos de pesar.

Conclusão: pelo fato de a presença da família na sala de emergência ser percebida, como positiva e benéfica sugere-se que os serviços de saúde, na medida de suas possibilidades, implementem esta prática. Contudo, é necessário que tais unidades sejam melhor preparadas para que se diminuam os percalços enfrentados pelos pacientes e suas famílias.

DESCRITORES: Família. Pacientes. Serviços médicos de emergência. Emergências. Percepção.

\section{PRESENCIA DE LA FAMILIA DURANTE LA ATENCIÓN DE EMERGENCIA: VIVENCIA DE LOS PACIENTES Y FAMILIARES}

\section{RESUMEN}

Objetivo: comprender cómo los familiares y pacientes adultos perciben la presencia de la familia en la atención de emergencia.

Método: estudio cualitativo que utilizó el Interaccionismo Simbólico como referencial teórico, y la Teoría Fundamentada en los Datos como referencial metodológico. La recolección de los datos se llevó a cabo en dos salas de emergencia, ubicadas en el sur de Brasil, entre octubre de 2016 y febrero de 2017, por medio de entrevistas abiertas con cuatro pacientes y ocho familiares.

Resultados: la presencia familiar en la atención de emergencia ha sido significada/percibida como positiva, como consecuencia de los beneficios identificados para pacientes, familiares y los profesionales de la salud. Sin embargo, la experiencia también ha sido marcada por percances para el binomio familiar-paciente como, por ejemplo, el miedo, las dudas, la angustia por la separación forzada de los miembros de la familia y la vivencia de los sentimientos de malestar.

Conclusión: por el hecho de que la presencia de la familia en la sala de emergencia es percibida como positiva y benéfica, se sugiere que los servicios de salud, en la medida de sus posibilidades, implementen esta práctica. No obstante, es necesario que tales unidades estén mejor preparadas para que se disminuyan los percances enfrentados por los pacientes y sus familias.

DESCRIPTORES: Familia. Pacientes. Servicios médicos de emergencia. Emergencias. Percepción. 


\section{INTRODUCTION}

The presence of the family during emergency care to follow cardiopulmonary resuscitation maneuvers and invasive procedures has attracted the attention of researchers and health professionals in different parts of the world, motivating debates and investigations. ${ }^{1-5}$ Important international organizations $^{6-7}$ have also endorsed and stimulated this practice. However, many emergency sectors do not allow families to be close to their loved ones during the care. ${ }^{7}$ This is because, doctors and nurses consider the practice controversial, requiring further studies. ${ }^{1-3}$

Another collaborative factor so that families are not routinely invited to witness emergency care is the nature of the care provided. At the moment of care, the severity of the clinical situation requires that the professionals' attention be focused on the victim - although sometimes only considering their pathophysiological aspects. ${ }^{8}$ However, professionals need to consider that care in an emergency unit evokes feelings, such as strangeness, anxiety, uncertainty and impotence, leading to emotional imbalance and even to family crisis. ${ }^{9-10}$ In the same way, when admitted to the Emergency Room (ER), the individual presents different fears and insecurities regarding the lack of knowledge of the environment, procedures, staff and the possible outcome of the situation. ${ }^{11}$

It is understood that the care in the ER should not be focused exclusively on the aggravations that triggered the search for the service and, also, dissociated from the care to the family of the patient. Scientific evidence suggests that professionals need to provide family members with the possibility of witnessing care because, thus, it is possible better understand the severity of the event, ${ }^{8,12}$ suffer less with anxiety and post-traumatic stress disorder ${ }^{13}$ and to elaborate more easily the process of mourning, when unavoidable. ${ }^{6,14}$ For the patients, the presence of the family during emergency care promotes a greater sense of security, comfort and support. ${ }^{15-16}$ In addition, the practice gives professionals the recognition and appreciation of the role that family members play in providing a more complete and accurate health history; more accurate explanations of patients' health needs. ${ }^{15,17}$

One aspect to be emphasized is the fact that studies that identified opinions of relatives and patients on the presence of the family during the emergency care, used a quantitative approach ${ }^{13-14,18}$ or they started from a hypothetical situation, without the interviewees having experienced the phenomenon concretely. ${ }^{15-16,19}$ Thus, it seems opportune that, in order to expand existing knowledge, it is indispensable to identify - from a qualitative perspective - the perceptions and experiences of family members and adult patients who, in fact, experienced the family presence in an emergency care unit.

The findings of this research may favor a more fruitful understanding of the specific experiences and needs of families and adult patients who experienced family presence during emergency care. This, in turn, has the potential to promote greater awareness among professionals in order to adequately meet the most elementary care demands of family members and patients, developing qualified care with them. Through the above, the objective of the present study was to understand the experiences of family and adult patients about the presence of the family in emergency care.

\section{METHOD}

A qualitative study using Symbolic Interactionism (IS ${ }^{20}$ as theoretical reference and Data Based Theory (TFD) as a methodological framework. ${ }^{21}$

Data collection occurred in the ER of two health units, which are located in different municipalities in the northwest of the state of Paraná, in the south of Brazil. Both services are maintained by the Unified Health System and serve emergency patients in an uninterrupted manner. At the time of data collection, these units did not have institutional policies or systematized routines that allowed the 
presence of the family frequently during care, which triggered sporadic occurrences and depended on the authorization of professionals. Thus, the sporadic cases considered for participation in this study.

It was decided to carry out the research in these two services due to differences in the geographic and social location of the population that uses them, as well as differences in the physical structure, professional profile and clinical conditions attended. For example, one of the emergency units is linked to a school hospital that is a reference to 30 municipalities of the 15th Regional Health Service of the state of Paraná, serving severe, complex and trauma victims and violence. The other is a Municipal Emergency Care Unit that provides assistance, mainly, to patients with clinical conditions and acute chronic diseases. These shades provided greater variability to the data.

Eight family members and four patients participated, all experienced the presence of the family in the ER. The inclusion criteria for the family members were: to be over 18 years old and to have an affective bond with a patient in emergency care. Participating patients, on the other hand, had the following criteria: being over 18 years of age, being in observation/hospitalized in the ER and not presenting trauma, injury or illness that prevented interpretation and/or response to the questions. Four patients and two family members who were not psychologically or emotionally able to answer the questions were excluded. It should be noted that as the interviews were performed, transcribed and analyzed one by one, there were no cases of family participants and patients from the same family.

Data collection took place in the period from October 2016 to February 2017, through audiotaped interviews after written consent of the participants, had a duration between 16 and 52 minutes and occurred in a reserved environment in the health unit or, in the case of patients, within the ER, but with the bed protected by screens. The generating questions were: a) Tell me what it was like to be present during the care of your relative in the Emergency Room (for family members) and b) Tell me what it was like for you to have a family member during your care in the Emergency Room (for patients).

As a result of the constant comparative method, the interviews took place concomitantly with the data analysis and the formation of the sample groups. As a result, it was necessary to adapt the interview scripts, including or withdrawing questions according to the development and deepening of the central category.

The first sample group consisted of five family members who had accompanied parts of the emergency care, witnessing some procedures. Analysis of the data from this first group showed that family members suffered from staying outside. When they entered the Hospital, the suffering remained, but they felt more confident about seeing the patient and accompanying the care, identifying benefits with their stay. On the other hand, once they were excluded again, they felt worried about the patient's clinical evolution and the care unfolding. Thus, the question: what are the experiences of relatives who can be with their loved ones for a longer period of time?

The second sample consisted of three relatives who remained with the patient, even after the end of the invasive procedures and their clinical stabilization, that is, they acted as companions in the ER. The inclusion of this family profile was useful in confirming that family members meant the experience as positive because they perceived the presence as beneficial in minimizing the suffering of the family-patient dyad. However, because they were longer in the ER, some mishaps for family members and patients were perceived more easily. In order to confirm the family members' perception of benefits and mishaps for the patients, the third sample group was composed of four patients who had received care at the ER under the family follow-up.

Post-transcribed and edited testimonials - for ease of understanding - were coded and compared one by one. ${ }^{21}$ As the interview was transcribed, the floating reading was performed to comprehensively comprehend the content of the text and then the open coding process was carried out with the help of the software QDA Miner ${ }^{\circledR}$. The construction of memorandums and diagrams began in this phase. 
Subsequently, the axial coding was used, comparing the initial codes of the same interview with those of the subsequent interviews. This allowed the grouping of such codes by conceptual similarities/differences in subcategories and later, the identification of the conceptual properties of the categories, through the establishment of provisional concepts. Finally, integration made it possible to identify the theoretical saturation, as well as to densify the categories and integrate them into the central category. In the analysis of the data, we also used the analytical mechanism called the paradigm, as a facilitator, which involves an organizational scheme that helps to collect and systematize the data, and to classify the emerging connections. According to this paradigm the condition; action/interaction; and the consequences of the phenomenon must be identified. ${ }^{21}$

The central category was validated with one patient and one relative from each of the health units, who had not participated in the study. For validation, the theoretical model elaborated was presented, explaining the relationship between categories and subcategories. They were then asked to evaluate the titles of the categories, the consistency and clarity of the relationship between them and which aspect (s) should be changed. The validation occurred in June 2017, through interviews conducted in the emergency units themselves, in a reserved space. The validators' testimony was recorded in audio, transcribed in full and compared to the previous analysis process. On this occasion it was identified that it was not necessary to make consubstantial changes in the central category entitled: "Presence of the family during emergency care: living a positive experience despite the mishaps".

The study was developed in accordance with the guidelines of Resolution 466/12 of the National Health Council. The interviewees signed the Informed Consent Form in two counterparts. The identification of the participants will be performed by the sample group to which they belong ( $\mathrm{G} 1$, G2 or G3), followed by the word "patient" or "relative" and by the respective number to the interview order. In the case of the relative, the degree of kinship with the patient was added (Examples: G1, Family 03 - daughter; G3, Patient 01).

\section{RESULTS}

\section{Characterization of the interviewees}

From the 12 participants, four were patients and eight were family members. Among the patients, the age ranged from 30 to 54 years old and three were male. The reasons that triggered the search for the emergency service were: neurological problems, cardiac and auto accident. Among the relatives, the age ranged from 35 to 63 years old and six were female. Five had up to four years of study and three had more than eight years of study. The family per capita income was between half and two minimum wages in both groups. The predominant kinship among relatives was spouse (three cases), followed by two mothers, one son, one sister-in-law and one niece.

\section{Presence of the family in the emergency room: living a positive experience despite the mishaps}

In this communication the full model (central category and its components) will be presented. The results demonstrate that family members and patients mean the phenomenon of experiencing family presence in the ER as positive, once they are perceived and highlighted consequences beneficial to those involved in the process of providing/receiving emergency care under family supervision. The benefits are perceived increasingly, as in a spiral. To a lesser extent, there is an emphasis on patients and family members. At the top of the spiral, the benefits for professionals are more strongly portrayed. It is also possible to perceive that, faced with the understanding that the family presence is positive and beneficial, relatives and patients wish that constantly, suggesting that everyone should have considered the possibility of experiencing emergency care with direct family support. 
It should be emphasized that in this study, the experiences considered are not confined to the presence of the family only during the emergency care itself (resuscitation and invasive procedures), since it includes other moments related to the patient's stay in the health unit. This is because, for patients and families, emergency care begins with the patient's entry into the ER or from the moment the prehospital care team arrives at the place of occurrence. Finalization is achieved when the discharge, the transfer to another sector/unit or death occurs. Therefore, the permanence of the patient in the ER, regardless of performing invasive procedures or the severity of the clinical picture, is understood as emergency care.

It is noteworthy that the identified phenomenon is influenced by conditions which demonstrate why, when and how it happens. Thus, the family presence occurs in a characteristic environment of emergency care, marked, in particular, by the presence of a limited physical structure and by a care centered exclusively on the pathological aspects of the patient. This is reflected in the experiences experienced by family members and patients, which occur in a transversal way during the family stay in the ER and are characterized by the lack of reception in the unit and little understanding of the relatives about the care situation. This directly influences their actions and interactions by allowing them to identify care, relational and structural aspects to be improved in order to qualify care (Figure 1).

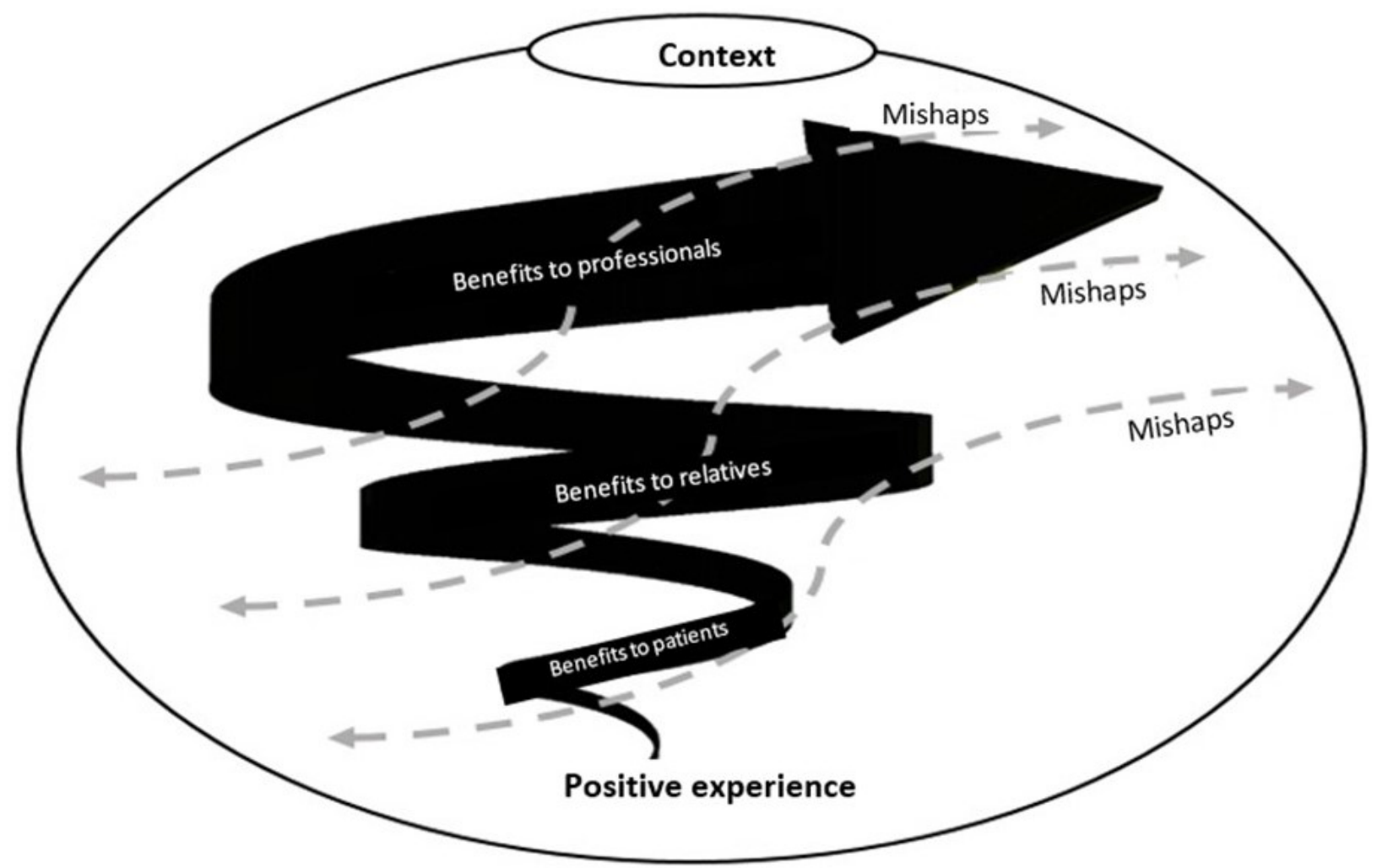

Figure 1 - Relation between the central category "Presence of the family during emergency care: living a positive experience despite the mishaps" and its categories 


\section{Benefits for patients with family presence in emergency care}

Relatives and patients, when they have the opportunity to experience the presence of the family in the ER, realize that this triggers benefits for the patients. Among them patients emphasize greater security, calmness and comfort, while relatives identify, in addition to security in care, the possibility of offering more individualized care, which will emotionally comfort and reassure the patient. Therefore, both believe that professionals need to consider such aspects so that the presence of families is more common and constant in ERs.

I calmed down when I saw her [the wife], looking at that little face I know was an indescribable sensation, I looked at her and thought: "okay, now I can rest easy, there's someone I know to take care of me." It was very nice of them to have allowed her to stay with me, waiting for the time to go to surgery because she gave me more security and I think I got more security for her [...], this had to be considered (G3, Patient 01). It's good to be here, because I'll help him. Since he's not moving his arms, there are times when he asks me to scratch his face and dry his forehead [...]. I make company, try to distract him not to be so worried about the surgery (G2, Family member 05 - mother).

Another point to emphasize is the fact that the family presence allows the exchange of information between patient-family-professionals, which is meant by the interviewees as beneficial for the patients. For example, in one case, the wife entering the ER provided information to the patient in accessible language about the surgery that would be performed and in another, the mother acted as the mouthpiece of the child who could not communicate effectively with the professionals.

The doctor talked to her before she came in here, told her what had happened, that I would need an emergency surgery. Would only wait for a woman to leave the operating room because she got a baby, so they gave her priority. The doctor explained these things to her, but had not said all this to me. I was already getting worried about the delay to go to the surgical center and she explained this to me, about the pregnant woman. Then I better understood and noticed there were people in greater need of care than I (G3, Patient 01). She spoke on my behalf at the time. If she had not been there, I would not have been able to talk to the doctor, and it may be that he was giving me dipyrone, and I'm allergic [...]. My mother was important because of this too (G3, Patient 02).

It is possible to identify that the presence of the family in the ER provides benefits to patients, related to safety, physical and emotional comfort, as well as providing information to patients and health professionals, allowing care to be provided and continuity, guaranteed.

\section{Benefits for families who have had the opportunity to be in the Emergency Room}

Relatives and patients, also identify benefits to families due to their presence in the ER. Initially, they recognize that the fact that the family members are distant from their sick loved ones, triggers the experience of intense suffering. In fact, the relatives could present complications of chronic diseases due to the stress experienced. On the other hand, the fact of accompanying/being present also causes suffering among the relatives, characterized by anguish, sadness, worry, regret and fear - while the loved one is in attendance.

But despite stress, family members prefer to "be with" - code in vivo - their relative during service. This is because, they believe that suffering, when it is made present, is less than that experienced on the outside, that is, distant from the patient. In this way, upon following care, the relatives indicate that they feel calm and secure, for certifying that the patient remains alive, receiving the necessary care and also, for obtaining more information about the clinical picture that, through the doubts, are more quickly and easily clarified by professionals. 
I found it very nice to be with him at that moment because, I pass security for him and at the same time she passes security for me. See, outside I was crying, desperate, did not know anything at all, without understanding the real seriousness of the problem. To me, he was full of those gadgets, the monitor and wires on all sides [...] and being with him, now I see that he is well, I know that the painting is serious, but I can see that everything is under the control of the professionals. So, we get calmer, safer (G1, Family member 04 - wife). He [the husband] was more relaxed to stay here with me, imagine being out there not knowing what is going on It must be very difficult. Because outside the person does not know anything, is not seeing and the doubt arises, the fear, while being in here, if you have doubt you ask the doctor soon, that is what he did [...]. Here the family member is already clearing doubts (G3, Patient 03).

It is possible to observe that patients and their families experience the benefits of family life, especially when suffering from emergency care, with the accompaniment of families, especially the reduction of suffering, as well as having their doubts more easily remedied, testifying that the patient remains alive and receiving assistance.

\section{The perception of patients and family members about the benefits of family presence in the emergency room for professionals}

Finally, family and patients believe that the presence of families in the ER also brings benefits to health professionals. Among them, they mentioned the fact that initially the relatives are able to offer information to the professionals about the previous medical history and the patient's current illness. This, according to them, provides security to the care, allows its continuity and; therefore, in addition to benefiting the patient, is also identified as positive for health professionals.

She [the mother] was talking to them [the professionals], talking about my liver problem, telling that on the way I vomited a lot of blood. Also said that I have allergy to dipyrone, these things. Then the doctor prescribed the medicines [...]. There was a moment that she helped me because the serum finished and there were no nurses in the Emergency Room, then the blood began to rise through the hose and I was already losing blood from the vomit, I could not let more blood go by the hose, then she called the nurse to put another serum, and she came and repaired, the blood stopped coming out [...] this all helps them too, to make the service better (G3, Patient 02).

As a result of the presence of the family in the ER, it is possible for the family members to observe the agility with which the service is provided; the quality of care and; the demonstration of concern for the patients by the professionals. Actions of this type are characterized as a benefit for professionals, when analyzed from the spectrum of recognition and appreciation of their work, as it triggers trust and satisfaction with the treatment received. In this regard, family members believe that all families should have the opportunity to be with their loved ones by witnessing the agile way in which assistance is provided.

You need to see the rush in the Emergency Room to service the patient when he arrives all bruised. I was astonished to see, because they do not stand still, it is all the time running and answering, searching for material, answering quickly. Nobody keeps chatting, nobody stays on the phone. It would be good if the family of these patients who arrive in the Emergency Room could accompany the care to see this rush with which they attend (G2, Family member 05 - mother).

Patients perceived that, from the presence of the relative in the ER, there is less request from the team of professionals to perform care, understood as of less complexity. Thus, professionals benefit from the division of care with family members.

Before she [the wife] came in I called the nurse to help change my foot position, because depending on the position it hurt a lot. After she [the wife] arrived, she helped me in this (G3, Patient 01). 
It can be understood that the presence of family members in emergency care is recognized as beneficial not only for the patient and the patient, but also for the health professionals who have the possibility of guaranteeing continuity of care and showing how care is provided.

\section{Context of emergency care: experiencing mishaps and indicating improvements}

The condition component is represented by the context in which the emergency care occurs and the action/interaction component is related to the experience of several mishaps by the family and patients during the stay in the ER, as well as the identification of aspects that can be improved, in the sense of them in the emergency context.

Relatives sometimes show that they feel alienated from the emergency service, that is, they do not perceive themselves as part of that space, because professionals do not seek to integrate them into care. Consequently, it is common the experience of nervousness and fear, mainly due to the lack of understanding of the signs and symptoms that the patient presents and the procedures being performed. Such nervousness sometimes produces distress in patients when they realize that their family member also suffers.

I was not fine, I think my pressure had dropped, but my mother stayed here, I realized that she was getting very nervous and nobody spoke to her. Watching her cry worried me a little (G3, Patient 02).

The sad and distressing feelings experienced by family members, such as compassion for the patient, derive from the fact that they take on the role of the other in the interactional process and try to understand their suffering. However, it can be observed that, immediately, they seek to return to their role as a family member who, when "being with" the loved one, feel themselves propelled to show calmness and confidence and, consequently, to reassure him.

It caused me much pain when the nurse went to get the vein in the neck, I put myself in his shoes. I had to hold on not to cry. Since I was there, I had to stay strong to give him strength. That's why I thought that despite the fear and the pain, it was good for me to be with him, to take his hand and say: 'I'm with you'. I think that with my presence he got a little calmer (G2, Family member 08 sister-in-law).

It is identified that for the relatives, the health professionals could modify their attitudes, in the sense of accepting and understanding their suffering. In addition, the fact that care is patient-centered and that professionals usually contact families almost exclusively to obtain information rather than to guide or clarify the patient's clinical and prognostic features, are also perceived as aspects that could be improved so that care is experienced in a less distressing and traumatic way.

Only the nurse came and asked things for me, she would come back and ask if he would take some controlled medication, if he had health problems, these things, but explanation would not give me. This was worrying me (G1, Family member 03 - daughter).

Given the lack of reception and explanations about what to expect about the clinical situation of the patients, the families question the health professionals about the behaviors and the assistance unfolding. However, this action causes the professionals to distance family members, even temporarily, from the ER.

The day I arrived, I was quite nervous when I saw him throwing up, I did not know if that was normal and I was asking the nurse [...], so much so that she asked me to go out and wait in the hallway. That was awful, because I had to be separated from my son. But on the other hand, it was good, because at that point I already understood that I have to stay calm to stay in the Emergency Room. We just get nervous because no one talks about whether this is normal or if the boy is getting worse, but l've already learned that if you do not calm down and quiet, the nurses will ask you to 
leave the emergency room and wait outside, because if you ask, they think that we are disturbing (G2, Family member 05 - mother).

Finally, in order to meet family needs, especially those of an emotional and psychological nature, the family members suggest that it would be relevant for a multiprofessional team to host, comfort and prepare families. In addition, they point out the need for professionals to allow the family member to enter, in addition to the timetable for visits, even for a short period of time.

Suddenly, putting together a multidisciplinary team, as we say at school, with psychologists and other professionals, would be important. That's because we get distressed, worried and sad and sometimes we can end up getting sick. Then, suddenly, this psychological help to be able to reach out to us and say, "We are together, we are with you", to improve our esteem, to bring a little more confidence that things can improve or even prepare us for the worst. It would be very interesting, it would be very important for us, the relatives (G1, Family member 03 - daughter).

It is identified that the family presence in the ER is marked by mishaps such as: fear, doubts, anguish by the forced separation of the family members and the experience of feelings of regret. To minimize such measured feelings as improvements in the environment and physical structure that allow them to be accommodated and accommodated; family integration in care; emotional needs of the family member and the patient by a multiprofessional team are suggested.

\section{DISCUSSION}

From the findings, it can be seen that patients and their families positively signify the presence of the family in the ER. This is because they pointed out several benefits for patients, family members and health professionals. Specifically in the case of patients, the benefits are related to the offer of greater comfort, safety and calm. These data corroborate the results of studies conducted in Brazil ${ }^{16}$ and in the United States ${ }^{15}$ which identified that, in the perspective of patients seen in emergency units, the family could, if present, support them during care, conveying mainly confidence. This is because support has the potential to reduce fear, distress and anxiety, feelings routinely attributed to the experience of severe illness and patient entry into an emergency service. ${ }^{11}$

In view of this understanding, it is believed that during the interaction process, professionals working in emergency sectors should put themselves in the patients' shoes, understanding the anguish that involves emergency care and which permeates the patient's mind seriously ill. Including the other in the relational field implies a true interior resolution and a great transformation in the modes of interaction, coexistence, respect for differences and reciprocity. ${ }^{22}$ This is why, often, this is a complex and laborious work to be developed and concretized by professionals, but must be relentlessly pursued in establishing a social interaction, in order to qualify the relational process and meet the patient's more specific demands in emergency care.

Benefits for families have also been identified. One of them is related to the possibility that the relatives, being in the ER, have their doubts minimized, providing them calmness and security. This finding was also found in a study carried out with seven Jordanian relatives who followed the resuscitation maneuvers of their loved ones, which demonstrated that being present during the care allowed the family to have access more quickly to the information about the picture and the evolution patient's clinic, minimizing their doubts. This was described by relatives as a propeller of feelings such as calmness and security, for they were aware of the events that involved caring for their loved one. ${ }^{12}$

The fact that relatives report doubts about emergency care seems to be a central issue in the studies. That is because, Chilean family members also pointed out that, when they attended the service, they perceived how little communication between the professional and the family, forcing them to interpret the language that the team used to capture more information. ${ }^{23}$ Despite the difficulties, family members perceived that the possibility of witnessing care provided more information than being 
away, making them characterize the experience as beneficial to the family in terms of acquiring more information. ${ }^{23}$

It is a consensus in the literature that offering information to the family member is relevant, namely, to clarify the diagnosis that motivated the search for the unit, the way the patient is being assisted, its clinical evolution, as well as bureaucratic-assistance developments. ${ }^{15}$ In this way, a greater sense of security is promoted in the family, as it identifies the quality of the care that the entity is receiving, which has the potential to facilitate family restructuring in the face of acute and severe illness. ${ }^{15}$ In addition, the relative, when well informed, facilitates and assists in the treatment of the disease. $^{3}$

It seems opportune that the professionals allow the presence of the family during emergency care, with the purpose of improving the communication and the provision of information because, knowledge about aspects related to emergency care, can facilitate the process of understanding gravity and acceptance of the disease, allowing the family to reorganize to overcome, in the best possible way, the stressful situation. ${ }^{9}$

It should be noted that the benefits most strongly identified by patients and relatives were related to health professionals, so it is relevant to discuss these data and seek to understand them. At first, the identification of more benefits for professionals from the experience of relatives and patients can cause some estrangement, since the expected one would be the more marked identification of their own benefits. Perhaps, this situation arises from the attempt of the interviewees to justify, for those who are notoriously more critical and contrary to the presence of the family, that the advantages are not limited to the patient-family dyad, but are also extensible and even more for health professionals.

It is interesting to consider that the opposite is also true. Studies performed with the professionals identify more strongly the potential benefits arising from the presence of the family for patients and their families, when compared to their own advantages. ${ }^{12,24}$ One of the few studies that show benefits to the team, pointed out that Canadian nurses perceived the practice as a propellant to improve their performance, by humanizing care. This allowed the professionals to remember the patient, not as a disease, but as a person who "belongs to someone". ${ }^{25}$ To further elucidate this issue, it seems necessary to develop research that provides the identification of the reasons that lead professionals and family/patients to perceive the practice as more beneficial to the other than to oneself.

Although, in general, the experience has been positively signified, the relatives identified some mishaps during their stay in the ER. One of the points scored was related to the perception that physical space was inadequate. Studies with relatives in different care settings (Chile and Australia) identified that the physical space of the emergency unit was not a perceived problem. ${ }^{4,23}$ Meanwhile, health professionals from the Middle East ${ }^{3}$ and Australia ${ }^{1}$, as well as patients in the United States ${ }^{15}$ have already shown concerns related to the small physical space for the adequate reception of the family in the ER.

Minimizing this problem of inadequacy in the physical space of the emergency units can be an important promoter of the presence of the family in the ER, since it appears as a frequent complaint between patients and professionals. ${ }^{1,15}$ However, it is recognized that in order to achieve this objective, it is necessary to invest financial resources, which for socioeconomic developing countries, where care is provided mainly by the public health system, this is an even greater challenge that requires the sum of efforts of professionals and managers to sensitize the public power in order to solve/ minimize the problem.

Other mishaps experienced by family members are related to the lack of reception by professionals, the difficulty of families understanding the situation, as well as the perception that care was patient-centered. It is believed that such situations can be at least in part minimized through the work of the facilitator - a health worker or unit chaplain trained for this purpose ${ }^{26}$ whose role is 
to prepare, host and give emotional support to the family member and, especially, informational support, through the decoding of what is occurring during the service in clear, objective, respectful and accessible language, to the individual's understanding. ${ }^{7}$

When the family members are advised about the clinical picture and the procedures that are being performed on the patient, anxiety, suffering and restlessness during follow-up decrease especially when this orientation is performed by a dedicated and attentive professional. ${ }^{7}$ In this context, in order to perform the function, the facilitator must have a keen sensibility to understand when to use the reception and communication, but also the therapeutic silence. ${ }^{3}$ Therefore, the availability of a multiprofessional team, as pointed out by the interviewees, may, in fact, constitute a strategy that drives the family presence in the ER, by increasing the number of professionals sensitized and trained to be with them and to support them.

This study has limitations to be considered. The first one is related to the fact that the interviews were carried out in the dependencies of the emergency unit during the experience of the phenomenon. This immediacy may have influenced participants' responses, since there was no time for reflection and meaning about events. However, this strategy reduced the possibility of bias of forgetfulness if the interviews were scheduled for later period, in addition, the greater ease of access to family members allowed a greater number of participants. In addition, the restricted number of cases investigated, as well as the fact that the phenomenon has been experienced in a heterogeneous way by the participants, may indicate that the potentially observable themes have not been exhausted, requiring caution when comparing their results.

\section{CONCLUSION}

For patients and family members, the presence of the family in the ER is positive, since they increasingly identify benefits for patients, families and professionals. However, the context of the ER, in which the phenomenon occurs, is marked by a lack of structure for the reception of family members, who face several mishaps during their stay in this environment.

When considering patient and family experiences, it is possible that strategies are developed that improve the experience of those involved with the family presence in the ER, such as the family reception that is considered as a deficit. Although welcoming the relative is related to the routine of the unit and the personnel dimension, this action, unlike hiring of personnel and structural reforms, only involves attitudinal issues and receptivity on the part of the professionals, that to resources.

For future studies, we suggest topics related to the insertion of the family into the ER during the care of their loved one, with the presence of a facilitator, whose function is to provide sufficient/ necessary informational support to family members so that families can be investigated. Patients experience the situation with greater support. This can sensitize managers and health professionals so that, to the extent of their possibilities, the presence of the family in the ER becomes increasingly gradual and increasingly systematized and qualified.

\section{REFERENCES}

1. Chapman R, Bushby A, Watkins R, Combs S. Australian emergency department health professionals' reasons to invite or not invite family witnessed resuscitation: A qualitative perspective. Int Emerg Nurs [Internet]. 2014 [cited 2017 Oct 02];22(1):18-24. Available from: https://linkinghub.elsevier. com/retrieve/pii/S1755-599X(13)00030-X

2. Masquelier E, Vandecasteele T, Verhaeghe S. Family presence during resuscitation: Perspective of family members and emergency care providers. Ressucitation [Internet]. 2015 [cited $2017 \mathrm{Apr}$ 09];96(1):5-42. Available from: http://www.resuscitationjournal.com/article/S0300-9572(15)00467$0 / p d f$ 
3. Bashayreh I, Saifan A, Batiha AM, Timmons S, Nairn S. Health professionals' perceptions regarding family witnessed resuscitation in adult critical care settings. J Clinical Nurs [Internet]. 2015 [cited 2017 Sept 12];24(17-18):2611-9. Available from: https://dx.doi.org/10.1111/jocn.12875

4. Giles T, Lacey S, Muir-Cochrane E. Factors influencing decision-making around family presence during resuscitation: a Grounded Theory study. J Adv Nurs [Internet]. 2016 [cited 2017 Sept 12];72 (11):2706-17. Available from: http://onlinelibrary.wiley.com/doi/10.1111/jan.13046/epdf

5. Buboltz FL, Silveira A, Neves ET, Silva JH, Carvalho JS, Zamberlan KC. Family perception about their presence or not in a pediatric emergency situation. Texto Contexto Enferm [Internet]. 2016 [cited 2018 Apr 24];25(3):e0230015. Available from: http://www.scielo.br/pdf/tce/v25n3/01040707-tce-25-03-0230015.pdf

6. Porter JE,Cooper SJ,Sellick K. Family presence during resuscitation (FPDR): Perceived benefits, barriers and enablers to implementation and practice. Int Emerg Nurs [Internet]. 2014 [cited 2017 Oct 22];22(2):69-74. Available from: https://linkinghub.elsevier.com/retrieve/pii/S1755$599 \times(13) 00065-7$

7. Oczkowski SJW, Mazzetti I, Cupido C. Family presence during resuscitation: A Canadian Critical Care Society position paper. Can Respir J [Internet]. 2015 [cited 2017 Oct 22];22(4):201-5. Available from: https://www.ncbi.nlm.nih.gov/pmc/articles/PMC4530851/

8. Youngson MJ, Currey J, Considine J. Current practices related to family presence during acute deterioration in adult emergency department patients. J Clin Nurs [Internet]. 2017 [cited 2017 Nov 11];26(21-22):3624-35. Available from: https://dx.doi.org/10.1111/jocn.13733

9. Zali M, Hassankhani H, Powers KA, Dadashzadeh A, Rajaei-Ghafouri R. Family presenceduring resuscitation: A descriptive study with Iranian nurses and patients' family members. Int Emerg Nurs [Internet]. 2017 [cited 2018 Jan 15];34(3)11-16. Available from: http://www. internationalemergencynursing.com/article/S1755-599X(17)30009-5/fulltext

10. Andrade ACS, Cardoso BD, Souza JEAP, Campos MC, Lima GZ, Buriola AA. Sentimentos de familiares de pacientes internados na emergência psiquiátrica: um olhar sobre a família. Ciênc Cuid Saúde [Internet]. 2016 [cited 18 Apr 2017];15(2):268-74. Available from: http://www. periodicos.uem.br/ojs/index.php/CiencCuidSaude/article/view/25964/17401

11. Olthuis G, Prins C, Smits MJ, Van-de-Pas H, Bierens J, Baart A.Matters of concern: A qualitative study of emergency care from the perspective of patients. Ann Emerg Med [Internet]. 2014 [cited 2017 Oct 11];63(3):311-9. Available from: http://www.annemergmed.com/article/S01960644(13)01331-0/fulltext

12. Masa'Deh R, Saifan A, Timmons S, Nairn S. Families' stressors and needs at time of CardioPulmonary Resuscitation: A Jordanian perspective. Glob J Health Sci [Internet]. 2014 [cited 2017 June 23];6(2):72-85. Available from: https://www.ncbi.nlm.nih.gov/pmc/articles/PMC4825218/

13. Jabre $P$, Belpomme $V$, Azoulay E, Jacob L, Bertrand L, Lapostolle F, et al. family presence during cardiopulmonary resuscitation. N Engl J Med [Internet]. 2013 [cited 2017 Feb 19];368(11):100818. Available from: http://www.nejm.org/doi/full/10.1056/NEJMoa1203366\#t=article

14. Jabre P, Tazarourte K, Azoulay E, Borron SW, Belpomme V, Jacob L, et al. Offering the opportunity for family to be present during cardiopulmonary resuscitation: 1-year assessment. Intensive Care Med [Internet]. 2014 [cited 2017 Apr 01];40(7):981-7. Available from: https://link.springer.com/ article/10.1007\%2Fs00134-014-3337-1

15. Twibell RS, Craig S, Siela D, Simmonds S, Thomas C. Being there: inpatients' perceptions of Family Presence During Resuscitation and Invasive Cardiac Procedures. Am J Crit Care [Internet]. 2015 [cited 2017 Apr 01];24(6):108-16. Available from: http://ajcc.aacnjournals.org/ content/24/6/e108.full 
16. Soares JR, Martin AR, Rabelo JF, Barreto MS, Marcon SS.Presença da família durante o atendimento emergencial: percepção do paciente vítima de trauma. Aquichan [Internet]. 2016 [cited 2017 June 18];16(2):193-204. Available from: http://www.scielo.org.co/pdf/aqui/v16n2/ v16n2a07.pdf

17. Hassankhani $\mathrm{H}$, Zamanzadeh V, Rahmani A, Haririan H, Porter JE.Family Presence During Resuscitation: A double-edged sword. J Nurs Scholarsh [Internet]. 2017 [cited 23 Mar 2017];49(2):127-34. Available from: http://onlinelibrary.wiley.com/doi/10.1111/jnu.12273/epdf

18. Soleimanpour H, Tabrizi JS, Rouhi AJ, Golzari SEJ, Mahmoodpoor A, Esfanjani RM, et al. Psychological effects on patient's relatives regarding their presence during resuscitation. J Cardiovasc Thorac Res [Internet]. 2017 [cited 2017 July 29];9(2):113-7. Available from: https:// www.ncbi.nlm.nih.gov/pmc/articles/PMC5516051/

19. Dwyer T. Predictors of public support for family presence during cardiopulmonary resuscitation: a population based study. Int J Nurs Stud [Internet]. 2015 [cited 2017 Jan 23];52(2):1064-70. Available from: https://linkinghub.elsevier.com/retrieve/pii/S0020-7489(15)00066-8

20. Mead GH. Mind, self and society. Chicago: University of Chicago Press;1934.

21. Corbin JM, Strauss A. Basics of qualitative research: Techniques and procedures for developing Grounded Theory. 4th ed. New York(US): SAGE Publications;2014.

22. Almeida DV. A filosofia levisiana numa experiencia de cuidar em enfermagem: a humanização decorrente da alteridade. Rev Enferm Ref [Internet]. 2013 [cited 2017 July 19];3(9):171-9. Available from: http://www.scielo.mec.pt/pdf/ref/vserllIn9/serllIn9a18.pdf

23. Dall'orso MS, Concha PJ. Presencia familiar durante la reanimación cardiopulmonar: la mirada de enfermeros y familiares. Cienc Enferm [Internet]. 2012 [cited 2017 July 19];18(3):83-99. Available from: http://www.scielo.cl/pdf/cienf/v18n3/art_09.pdf

24. Havugitanga P, Brysiewicz P. Exploring healthcare professionals' perceptions regarding familywitnessed resuscitation in a hospital in Kigali, Rwanda. South Afr J Crit Care [Internet]. 2014 [cited 2017 Apr 30];30(1):18-21. Available from: http://www.scielo.org.za/pdf/sajcc/v30n1/06.pdf

25. Mcclement SE, Fallis WM, Pereira A. Family Presence During Resuscitation: Canadian Critical Care Nurses' Perspectives. J Nurs Scholarsh [Internet]. 2009 [cited 2017 Feb 26];41(3):233-40. Available from: https://dx.doi.org/10.1111/j.1547-5069.2009.01288.x

26. Odgers J, Fitzpatrick D, Penney W, Shee AW. No one said he was dying: families' experiences of end-of-life care in an acute setting. Aust J Adv Nurs [Internet]. 2017 [cited 2018 Feb 19];35(3):2131. Available from: http://www.ajan.com.au/Vol35/lssue3/3Odgers.pdf 


\section{NOTES}

\section{ORIGIN OF THE ARTICLE}

Article extracted from the the thesis - Presence of the family during emergency care: experiences and perceptions of patients, relatives and health professionals, presented to the Graduate Program in Nursing, Universidade Estadual de Maringá, 2017.

\section{CONTRIBUTION OF AUTHORITY}

Study design: Barreto MS, Marcon SS.

Data collection: Barreto MS.

Data analysis and interpretation: Barreto MS, Garcia-Vivar C, Angelo M, Oliveira MLF, Matsuda LM, Marcon SS.

Discussion of the results: Barreto MS, Garcia-Vivar C, Angelo M, Oliveira MLF, Matsuda LM, Marcon SS Writing and/or critical review of content: Barreto MS, Garcia-Vivar C, Angelo M, Oliveira MLF, Matsuda LM, Marcon SS.

Review and final approval of the final version: Barreto MS, Garcia-Vivar C, Angelo M, Oliveira MLF, Matsuda LM, Marcon SS.

\section{FUNDING INFORMATION}

Scholarship for Sandwich Ph.D for the lead author. Coordination of Improvement of Higher Level Personnel (CAPES). Process No.: 99999.003873/2015-03.

\section{ETHICS COMMITTEE IN RESEARCH}

Approved in the Committee of Ethics in Research with Human Beings of the Universidade Estadual de Maringá opinion 1,888,327, Certificate of Presentation for Ethical Appreciation: 62787916.4.0000.0104)

\section{CONFLICT OF INTERESTS}

No any conflict of interest.

\section{HISTORICAL}

Received: April 28, 2018.

Approved: August 6, 2018.

\section{CORRESPONDENCE AUTHOR}

Mayckel da Silva Barreto.

mayckelbar@gmail.com 